\title{
Kajian Program Happy Being Me dan Healthy Me untuk Pencegahan Ketidakpuasan Tubuh Remaja yang Dilakukan pada Anak Sekolah Dasar
}

Ira Dewi Ramadhani

Pendahuluan

Masa remaja merupakan masa transisi dari masa kanak-kanak ke masa dewasa yang pada fase inilah perubahan fisik terkait pubertas. Citra tubuh erat kaitanna dengan ketidakpuasan tubuh yang merupakan akibat dari kesenjangan antara bentuk tubuh aktual dengan bentuk tubuh ideal yang diharapkan. Hal ini telah menjadi perhatian para peneliti di dunia, seperti hasil penelitian yang dilakukan oleh Linda di Australia, sekitar $70 \%$ remaja perempuan dan $45 \%$ remaja laki-laki ingin merubah berat badan dan bentuk tubuhnya.

Semakin kuatnya arus globalisasi mengakibatkan ketidakpuasan terhadap tubuh telah dijumpai pada remaja Indonesia, baik perempuan maupun laki-laki. Penelitian di siswa perempuan (20\% diantanya menglami gangguan makan) dan uan (20\% dian Sari $50 \%$ siswa laki-aki $(7 \%$ ketidakpuasan berat) mengalami ketidakpuasan terhadap tubuhnya. Hal tersebut dapat menyebabkan perilaku pengontrolan berat badan yang tidak tepat maupun kebiasaan makan yang buruk sehingga membahayakan perkembangan fisik dan kognitif pada masa remaja, bahkan berdampak pada kesehatan mental.

Ketidakpuasan yang muncul akibat cara pandang tubuh ideal tersebut ditunjang oleh faktor sosial budaya yang mempengaruhi, yaitu media, teman sebaya, dan juga faktor sosial budaya ilu, butuh upaya untuk mengontrol Namun sayangnya di Indonesia masih belum ada upaya. khusus tersebut. Salah satu upaya yang sudah diterapkan di beberapa Negara Barat adalah program pencegahan ketidakpuasan tubuh yang diterapkan di Sekolah Dasar yaitu Happy Being Me dan Healthy Me. Happy Being Me merupakan program pencegahan ketidakpuasan tubuh yang penelitiannya dilakukan di Inggris sedangkan Healthy Me adalah program yang dilakukan di Australia dengan beberapa metode yang berbeda.
Tujuan

Diseminasi informasi terkait cara pencegahan ketidakpuasan tubuh remaja yang dapat dilakukan lebih dini ketidakpuasan tubuh remaja yang
melalui program di Sekolah Dasar.

Seperti apa program Happy Being Me dan Healthy Me?

Program pencegahan ketidakpuasan tubuh bernama Happy Being Me berupa edukasi, diskusi, dan role play yang dilakukan selama 3 minggu ( 1 minggu=1 sesi) pada anak $S D$ usia 10-11 tahun hanya ( selama 4 mingu pada prok SD usia 8-11 the dlakukan metode serupa namun fokus pendekatannya berdasarkan jenis kelamin menunjukkan hasil yang lebih baik, yaitu anak perempuan maupun laki-laki mengalami peningkatan signifikan pada beberapa aspek citra tubuh. Selain itu beberapa cara menarik yang digunakan dalam program Healthy Me adalah mempromosikan makanan sehat dan kebiasaan olahraga.

\section{-Happy Being Me}

1. Media
2. Mergatasi ejekan
3. Perbandingan tubuh

-Kepuasan tubuh dan self esteem hanya meningkat pada
perempuan

- Healthy Me

1. Ragam penampilan
-2. Role model
-3. Aktifitas kognitif
-4 Kestantan fisik

-4.
- Resenatan fisik
- Review Materi

Body esteem dan muscle esteem meningkat pada laki-laki dan perempuan
Lesson Learned

Program pencegahan ketidakpuasan tubuh akan efektif untuk diadopsi dengan menerapkan metode yang berbeda untuk siswa SD laki-laki dan perempuan. Program ini harus dilakukan berkelanjutan dalam jangka waktu tahunan dengan evaluasi berkala setiap 3 bulan sekali. Dibutuhkan pula peran dari orang tua siswa untuk mendukung penerapan program dengan cara mendampingi pengerjaan PR (pekerjaan rumah) terkait program serta mendampingi dan memberi penjelasan penampilan fisik.

\section{(4) \\ 结 headspace \\ Acfion Schools! BC

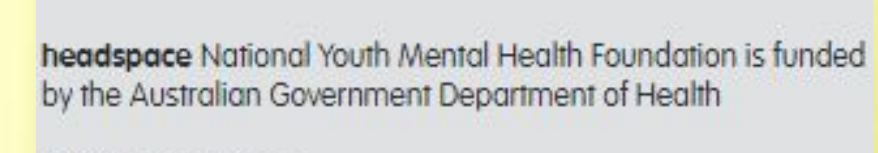 Promoting Healthy Living}

Apakah dapat dilaksanakan di SD Indonesia? -ebih sesuai di SD Negeri ataupun Swasta favorit di Kota Besar, menimbang faktor resiko ketidakpuasan tubuh lebih besar pada daerah urban.

kelatihan dapat melaksanan program dengan sederhana.

Implikasi praktis
Program ini dapat dilakukan dan di evaluasi oleh Wali Kelas / Program ini dapat dilakukan dan di evaluasi oleh Wali Kelas
Guru BK sebagai program khusus atau bagian dar
pentan pembelajaran tematik terpadu.

Rekomendasi Penerapan
Persiapan
* Wali Kelas dan/atau Guru BK mengadakan pertemuan
dengan wali murid kelas 3 SD untuk pemberian informasi
program yang akan dilaksanakan, edukasi, serta
pembagian leaflet terkait program.
* Sebelum program dimulai dilakukan pengukuran dengan
kuesioner

Rekomendasi Penerapan.

Waktu

* Program khusus $\rightarrow$ Setiap (4 sesi, seminggu sekali) Sisipan temati $\rightarrow$ sekali oleh Wali Kelas

Penekanan Khusus * Perempuan: diskusi terkait penampilan baik dan sehat menggambar diri (hobi) diskusi terkait olahraga (idousi terkail olahraga pertemanan)

Referensi

[1] Grogan S. (2016) Body Image: Understanding Body Dissatisfaction in Men Women and Children. 3rd edn. Newyork: Routledge, Taylor and Francis Group. Available at: https://books. google.co.ld/books? ?sbn=1317400437.

2] Gattan, K. H. (2013) BODY IMAGE N ADOLESCENCE: Through the Lenses Gothenburg. Linda Smolak (2012) Appearance in Childhood and Adolescence. Edited by N Rumsey and D. Harcour. London: OXF

(A] Yuliana, Budiar Ningrum and Dieny, Fillah Fithra. (2013) Ketidakpuasa Yuliana, Budiar Ningrum and Dieny, Fillah Fithra. (2013) Ketidakpuasan
Terhadap Citra Tubuh dan Kejadian Female Athlete Triad (FAT) pada Remaja Putri. Journal of Nutrition College: Universitas Diponegoro.
Ira Dewi R Panungal Binar (2014) Perbedan Citra Tubuh Berdasarka Status Gizi Remaja Putra. Journal of Nutrition College:Universitas Diponegoro. [6] Ricciardelli, L. A., McCabe, M. P. and Banfield, S. (2000) 'Body image and (10) 10.1016/500223999(00)00159-8.

Bird, E. L. et al. (2013) 'Happy being me in the UK: A controlled evaluation of 8] McCabe, M. P. et al. (2017) 'Healthy me: A gender-specific program to addre body image concerns and risk factors among preadolescents', Body Image. 